\title{
MODELLING WHEAT GRAIN FLOW DURING SOWING BASED ON THE MODEL OF GRAIN WITH SHIFTED CENTER OF GRAVITY
}

Vladislav Zubko ${ }^{\mathrm{a}}$, Viktor Sirenko ${ }^{\mathrm{b}}$, Tetiana Kuzina ${ }^{\mathrm{c}}$, Viktor Onychkod, Serhii Sokolike, Hynek Roubik ${ }^{\mathrm{f}}$, Milan Koszel ${ }^{\mathrm{g}}$, Taras Shchur ${ }^{\mathrm{h}}$

a Department of Tractors, Agricultural Machinery and Transport Technologies, Sumy National Agrarian University, Ukraine, e-mail: zubkovladislav@ukr.net, ORCID 0000-0002-2426-2772

b Department of Energy and Electrical Engineering, Sumy National Agrarian University, Ukraine, e-mail: snaumen105@ukr.net, ORCID 0000-0003-0831-6563

${ }^{\mathrm{c}}$ Department of Tractors, Agricultural Machinery and Transport Technologies, Sumy National Agrarian University, Ukraine, e-mail: 300860@ukr.net, ORCID 0000-0003-0462-2475

d Department of Selection and Seed Production, Sumy National Agrarian University, Ukraine, e-mail: onichko@gmail.com, ORCID 0000-0003-0584-319X

e Department of Tractors, Agricultural Machinery and Transport Technologies, Sumy National Agrarian University, Ukraine, e-mail: sokolik1009@gmail.com, ORCID 0000-0003-4496-8681

f Department of Sustainable Technologies, Czech University of Life Sciences Prague, Czech Republic, e-mail: roubik@ftz.czu.cz, ORCID 0000-0002-7498-4140

g Department of Machinery Exploitation and Management of Production Processes, University of Life Sciences in Lublin, Poland, e-mail: milan.koszel@up.lublin.pl, ORCID 0000-0001-9527-8459

h Department of Cars and Tractors, Lviv National Agrarian University, Ukraine, e-mail: shchurtg@gmail.com, ORCID 0000-0003-0205-032X

*Corresponding author: e-mail: shchurtg@gmail.com

\begin{tabular}{l}
\hline ARTICLE INFO \\
\hline Article history: \\
Received: December 2021 \\
Received in the revised form: \\
January 2022 \\
Accepted: February 2022 \\
\hline Keywords: \\
germ, \\
grain model, \\
impact of orientation, \\
seed orientation, \\
winter wheat
\end{tabular}

ABSTRACT

Winter wheat is one of the widespread crops in Ukraine. The search for methods to increase the yield and consumer properties of wheat, without compromising environmental safety, is one of the important scientific problems. The principles of precision agriculture point to the proper positioning of the seeds, recommending the method of "upward germination" (positioning the wheat germ vertically). The main objective of this study was to develop a new geometric model of wheat grain with a displaced centre of mass, as well as to conduct the theoretical research and numerical experiments on the orientation of grains using their multiple impact interaction with inclined surfaces. A new model of germ consisting of two different end semispheres and amid-line truncated cone was proposed, with a displaced centre of mass. Taking into account the physical properties of the objects, the concept of arrangement of gravity orientation of seeds in a stream was applied. This concept was based on various ratios of kinetic parameters of bodies with a displaced centre of gravity following an impact. The results showed that the orientation process can be controlled by changing the inclination angles and the length of the walls of the tray orientator within the working velocity range. This must be done before impact interaction of $0.2-0.3 \mathrm{~m} \mathrm{~s}^{-1}$ when the inclination angles of the impact interaction planes are $24-32^{\circ} \mathrm{C}$ 


\section{Introduction}

Winter wheat is the main grain crop in Ukraine, with over $6.5 \mathrm{ml}$ hectares planted each year. Therefore, the search for new ways to sow its grains to increase its yield is of great interest. Ensuring the highest efficiency of each stage of the process of sowing is the most important task in growing winter wheat. The most researched processes include the selection of wheat variety, its storage, pre-sowing, and application and positioning grain in the soil (Chenu et al., 2017; Chu et al., 2016). Furthermore, a large number of studies are focused on the choice of density, uniformity and depth of crops under different weather conditions, as well as on crop row orientation (Borger et al., 2010; Dai et al., 2016).

Vertical sowing of corn kernels, but with a germ positioned downward, is being extensively studied and practised (Grishchenko and Roslyakov, 2009; Koller et al., 2016). The positive effect is enhanced by pressing the seeds into the soil. Besides, the effect of seed orientation on germination and grain yield was determined by Kouamé et al. (2015) and Uniyal et al. (2007).

The optimal depths of sowing of wheat seeds at different humidity values and its distribution in soil were found in the work of Schillinger et al. (1998). The main conclusion is that the wheat germ should be placed at a maximum depth that would ensure access to soil moisture. Moreover, the vertical position of the grain with the germ at the top (Zubko et al., 2017a) improves moisturization since the endosperm is located in the wetter layers of soil. In this case, of course, the depth of the seed groove should be increased by the length of the grain $(\approx 8 \mathrm{~mm})$.

In their previous work (Kuzina et al., 2018), the authors observed a 10-12\% increase in winter wheat yields when the germ is sown upwards, both in the laboratory and in field experiments.

The expediency of this method of grain sowing is supported not only on the improved moisture supply of the endosperm but also by the accelerated sprouting of the first pairs of roots near the germ. Under the influence of geo- and hydrotropic factors (Kuzina et al., 2018), they grow intensively downward. The result of changing the position of the grain can be attributed to the phenomenon of "soft" stress.

Vertical sowing of winter wheat (upward germination) (Zubko et al., 2017a) and a device for grain orientation (Zubko et al., 2017b) can significantly improve the rates of growth and crop yield of the crop significantly (Kuzina et al., 2018).

The need to align the endosperm part of the grain with the flow is a peculiarity of the orientation of winter wheat seed. Mechanical engineering aims for effective automation of assembling processes to increase the use of relative orientation devices. This was broadly discussed by various researchers such as Lebedovskiy et al. (1985), Gusev (1976) and Bozhydarnik et al. (2005). Furthermore, Vladzievskiy and Belousov (1966), Boothroyd and Dewhurst (2002), Suri (1995), and Redford and Chal (1994). All of the above authors discussed the principles of constructing orientation units, which were used in the development of an orientation device for winter wheat grains.

Primary orientation is changing the position of grain from a random to a defined position on the default plain. During the secondary orientation, the grains change one stable position to another gradually until they all become oriented in the predetermined position. The orientation unit must include three units: I) defining, II) controlling and III) executing. In most cases, the defining or fixing unit is two planes that intersect at an angle close to $90^{\circ}$. During 
secondary orientation, it is usually the surface of the trays that plays the role of the defining plain that helps to reposition the grains (Bozhydarnik et al., 2005).

To promote active orientation of the grains with the displaced centre of gravity, it is necessary to make a cutout on the tray, adapting the size so that the grain can fit into it while driving. When the grain moves forward through a narrow end, it enters the opposite side of the cutout. Next, it falls out into the cutout from the rear. They tip on the heavier side and fall out downwards (Vladzievskiy and Belousov, 1966).

The main disadvantage of the devices used is the low velocity of the processes in a single row. There is a moment when the velocity drops to zero, and then is restored due to gravity. To solve this technical problem, it is necessary to carry out one or more stages of re-orientation through impact by increasing the width of the flow, which requires further research (Lebedovskiy et al., 1985).

Theoretical and practical development of agricultural sowing machinery is closely related to the model that considers grain to be a working object. Preliminary research of the general laws of motion of the material in the working units leveraged the models of material particle and spherical body describing the motion of the large volumes of grains (Zavgorodniy et al., 2010).

Recently, due to the increased interest in the development of high-tech processes, it is possible to trace the application of the models to real grains (Torres et al., 2017; Troshkin et al., 2019). Modern seed separation and sowing technology requires more detailed consideration of the weight and shape of the seed.

The analysis of the methods of orienting used in mechanical engineering and construction showed that the main method is orientation by shape. For small objects of organic origin, such as grains, we recommend using the movement of particles after impact in the orientation process. Based on the above, the authors adopted two end spheroids of different diameters connected by a truncated cone as the most accurate geometric model for describing the movements of the egg-shaped wheat grain.

This study aims to develop a new geometric model of wheat grain with a displaced centre of mass. Its aim is also to conduct theoretical research and numerical experiments on the orientation of grains. Calculating multiple impact interaction of the grain with the inclined metal surfaces will allow determining the ranges of the operating parameters of the orientation device.

\section{Material and methods}

\section{Measurement of the size of the grain model}

Our model axisymmetric three-dimensional unit consists of two spherical sectors and a truncated cone (Fig. 1, a, b). The end part of the germ is a circle of radius $R$; the end part of the endosperm is a circle of radius $r$ located along the horizontal axis, the distance between their centers is $O_{1} O_{2}$, and the total length of the model is $L$. 

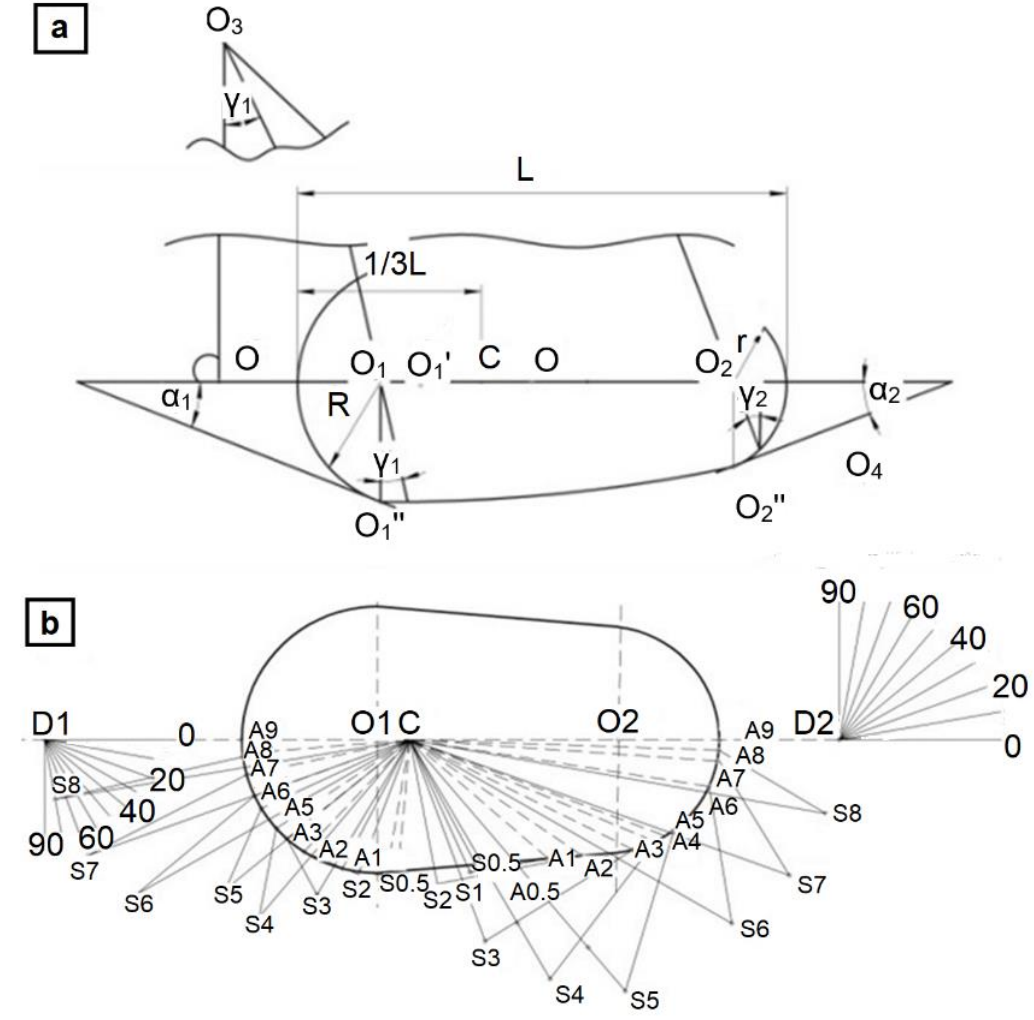

Figure 1a. Scheme of the model elements. Figure 1b. Estimation of the distances between the centre of mass and points of contact.

The measurement of the chamfering of the outer contours was carried out by examining the photos of the grains in two projections on the appropriate scale. A set of round templates of different diameters (radius) was used. The model includes the following dimensions: length of the grain $L=7 \mathrm{~mm}$; radius of the germ $R=2 \mathrm{~mm}$; endosperm radius $r_{l}=1.5 \mathrm{~mm}$.

The results of the measurement of the average size of each delivery of grain (and points contacts of the grains in two projections on the appropriate scale using set round templates of different diameters (radius). The model has $0.331-0.335 \mathrm{~L}$, which is close to $(1: 3) \mathrm{L}$ (Fig. 1a).

\section{Determination of the grain's contact points with the plain}

Contact of the grain with a plain at an angle $\alpha$ to the horizontal axis can be observed in the germ zone with radius $R$. The distance from $C$ to a plane is:

$$
y_{c}=R+\left(\frac{L}{3}-R\right) \sin \alpha
$$


Modelling wheat grain...

To chamfer a smaller radius $r$ for the endosperm part, the following formula is used:

$$
y_{c}=r+C O_{2} \sin \alpha=r+\left(\frac{2}{3} L-r\right) \sin \alpha
$$

The moment of inertia of the model is presented by the simplified version of the sum moments in three parts. The end parts are hemispheres, and the cone generatrix is a straight line. The validity of the model was verified according to the position of the center of mass. The calculated value of the radius of inertia for the given dimensions was $(\rho)^{2}=5.17 \mathrm{~mm}^{2}$.

The possible contact point $A$ (Fig. 1b) of the grain side is located on tangent lines, drawn at different angles to the contour. $C A$ is the distance between the centre of gravity and the contact point; point $S$ is an intersection of the perpendicular from the centre of gravity $C$ to the line $A S$ which is tangent to the contour at the contact point $A$. CS is the length of the perpendicular. $S A$ is a distance from the intersection point of the perpendicular lines (at the right angle) to the contact point $A$.

In the experimental verification of the process of orientation by free distribution of grains both on the element and the segments, a load consisting of mixed grains measuring from $0.051 \mathrm{~g}$. to $0.053 \mathrm{~g}$., was used. The proportion of the oriented grains (to "upward germination" end position) was determined after their slowing down on the elongated sloping tray where the slope does not exceed the friction angle and ranged from $77 \%$ to $90 \%$.

\section{Results and discussion}

The results of calculations on the dependency charts $C A=f(\alpha) ; C s=\varphi(\alpha) ; S A=\psi(\alpha)$ (Fig. 2) shows twofold and fivefold reduction of distances from the centre of gravity to the contact point and the segment $A S$ during the contact of the model part of the germ. This indicates that the impact orientation of the model is possible.

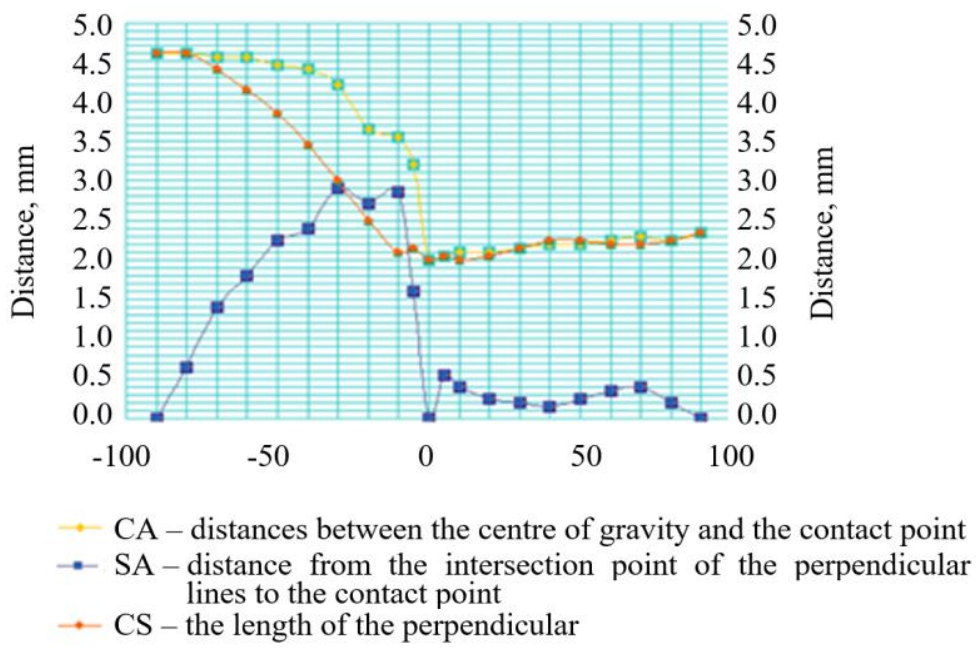

Figure 2. Distances between the centre mass and contact points, depending on the angle of contact $\alpha,{ }^{\circ}$. 
The impact interaction of a flat grain model moving vertically towards the inclined plane at the initial horizontal axis position can take place on the germinal, or endospermic part.

Normal and tangent components of the velocity of the centre of mass and the angular velocity of the model after the impact were comprehensively discussed by Lapshin (2014). In this research, the dry friction force and the distribution of the impact process on two phases was taken into account. Based on the scheme investigated, the author established that the impact of a body on a rough surface always begins with slipping, either until it stops, or in the deformation phase, or when restoring the shape of the contact point of grains. This subject was also researched by Dyakonov and Shipulin (2016), who examined the wheel-workpiece interaction.

The results of the research confirm the process of multiple interaction of the grain with the surface. Therefore, the the parameters of the grain movement before the next impact were investigated. When these values have been found, the post-impact parameters were calculated, to determine to either continue or stop making elaborate calculations in the model operation. So, at the first impact of the germinal part with the plain at the angle $\alpha$, the grain should not return to an angle exceeding $90^{\circ}$ to maintain the "upward germination" orientation. When the impact of endosperm is observed, it is necessary to obtain the grain axis rotation at an angle exceeding $90^{\circ}$ but less than $180^{\circ}$ after the first contact. The smaller values of the rotation angles at a significant angular velocity can lead to a collision in the next cycle.

Figure 3 shows the geometrical scheme for the contact moment of the model $K_{1}, K_{2}$ both of the germ and the endosperm, respectively. It was used as a foundation for the equations expressing the displacement of the centre of mass at the beginning and at the end of the flow.

$$
y^{\prime \prime}=\frac{R+\left(\frac{L}{3}-R\right) \sin \varphi^{\prime}}{\cos \alpha}+W_{3} t-\frac{g t^{2}}{2}
$$

On the other hand, the coordinate $y^{\prime \prime}=c^{\prime \prime} z^{\prime}$ :

$$
y^{\prime \prime}=\frac{\left(\frac{2}{3} L-r\right) \cos \left(\frac{\pi}{2}+\varphi^{\prime}-\omega+t\right)+r}{\cos \alpha}-H_{3} \tan \alpha t
$$

Thus, equations (3) (4) are obtained, with two transcendental variables $y^{\prime \prime}$ and no algebraic solution. The trigonometric function of the cosine expressed as the Taylor series expansion, where the second component contains the value $t_{2}$, is used. Therefore, the system is solved as a quadratic equation (5):

$$
R+\alpha \sin \varphi^{\prime}+W_{3} \cos \alpha t-\frac{g t^{2}}{2} \cos \alpha-b \gamma+b \gamma \frac{c^{2}}{2}-b \gamma c \omega t+b \gamma \frac{\omega^{2} t^{2}}{2}-r+
$$

$H_{3} \sin \alpha t=0$

where:

$W_{3}, H_{3}$ are the initial vertical and horizontal components of the velocity of the centre of mass after the first impact. 


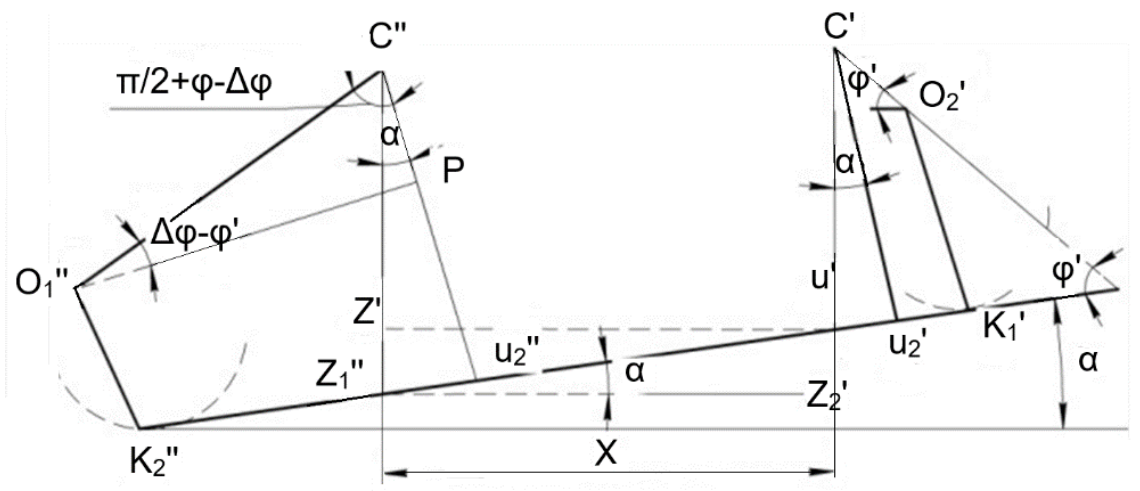

Figure 3. Position of the grain axis at the moment of contact with the impact interaction plane.

The solution of this equation is $t_{1.2}=\frac{-B \pm \sqrt{B_{1}^{2}-4 A_{1} C_{1}}}{2 A_{1}}$, where the coefficients are:

$$
A_{1}=\frac{b \gamma}{2} \omega^{2}-\frac{g}{2} \cos \alpha ; B_{1}=W_{3} \cos \alpha-b \gamma c \omega+H_{3} \sin \alpha ; \mathrm{C}_{1}=R+\alpha \sin \varphi^{\prime}-
$$
$b \gamma\left(1-\frac{c^{2}}{2}\right)-r$

The obtained positive values the roots of the quadratic equation (6) provide the values of approximate flow time, the centre mass of the grain and their position, as well as determine the magnitude of the variable $t$. These values are also used as the approximate for further findings, using e.g., Microsoft Office Excel.

The mathematical tools allows tracing the entire process of interaction of the grain model with the impact device at different angles of inclination $\left(10-44^{\circ}\right)$. It also allows determining the encounter velocity at $0.05-0.35 \mathrm{~m} \mathrm{~s}^{-1}$. The calculations are made using block diagrams. The peculiarity of the results is identical correlation between the angular rebound velocity of the model at the identical inclination of the plane, but at a different flow velocity, 1.8-2.5 times the range of inclination, and close to the friction angles. This allows for developing schemes for guaranteed grain orientation suitable for "upward germination".

The "upward germination" grain model (i.e., when the centre of mass is shifted towards the surface), moves upwards after the impact. However, due to the small eccentricity between the centre of mass and the impact pulse, it receives a slight angular velocity and returns at an angle less than $90^{\circ}$, while keeping the orientation.

If on approach the grain's velocity is in the same range, but oriented to "downward germination", and the endosperm part takes on the initial impact, its rotational energy is sufficient to turn the axis at the desired angle to the approximate value $\pi$ for the next two or three impacts and takes the necessary "upward germination" position.

The results of the numerical experiment investigating the impact interaction of the horizontal model, in which the germ is oriented upwards revealed the maximum permissible values of the linear velocity of $0.3 \mathrm{~m} \mathrm{~s}^{-1}$ (Fig. 4), where the rotation angle of the model's axis 
does not exceed $80^{\circ}$. When the velocity is lower, at any angle of inclination, the post-impact position of the grain model's axis is maintained.

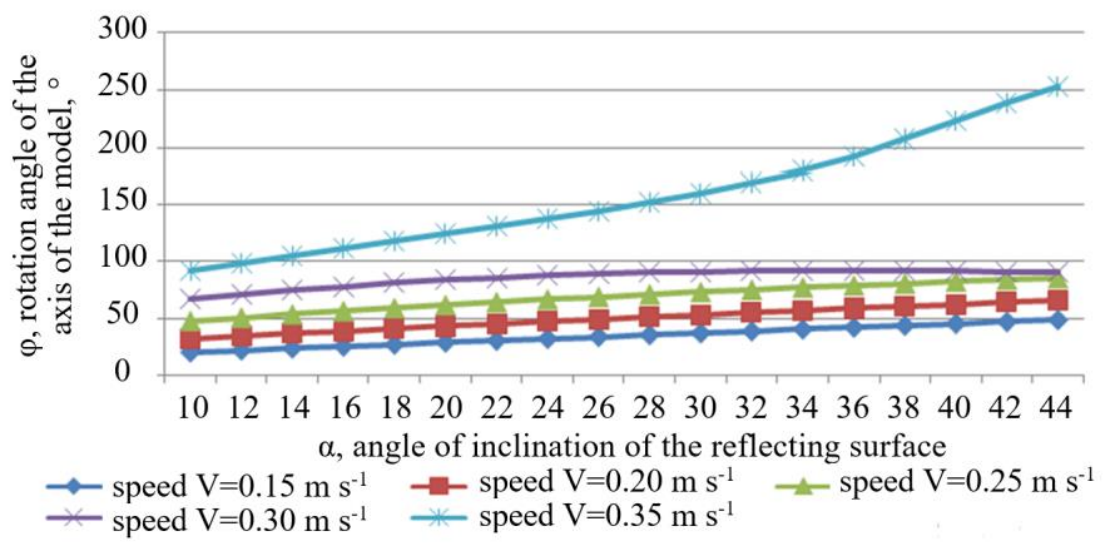

Figure 4. Dependencies of the rotation angles on the angle of inclination of the impact interaction plane and the velocity of the model at the first impact of the grain.

According to the calculations, the angles of rotation of the model's axis are insufficient at the first impact of the germ. However, due to the high initial angular velocity (Fig. 5), the model continues rotating around the centre of mass, and thus the necessary values of the angles of rotation after the second and third impact can be obtained. These results reflect the findings of Zotikov and Lashkov (2014) who also investigated the impact interaction of ellipsoid-shaped objects against a plain. They found that the ellipsoid gains rotation during the impact. This can lead to its multiple interactions with the surface. However, the authors investigated the impact at an initial velocity of $100 \mathrm{~m} \mathrm{~s}^{-1}$. The results of this study showed that the initial velocity of the model should not exceed $0.3 \mathrm{~m} \mathrm{~s}^{-1}$. Only in this case, the grain model will not rotate after impacting the surface, which will allow positioning it after the next two interactions. Maiatskaia (1999) also investigated the interaction of wheat grains with the surfaces of various working bodies of agricultural machines, using the wheat grain model in the form of a spheroid. In particular, an off-center impact of a grain of wheat on the surface of a breaker beater was considered. The range of variation of the reflection angle was 21.64-69.27 . However, the author did not consider the rotation of the model when sliding along an inclined plane. In addition, the use of the discussed model of grain in the form of two end spheroids of different diameters connected by a truncated cone, instead of a spheroid, allows for a better description of the actual impact process. 
Modelling wheat grain...

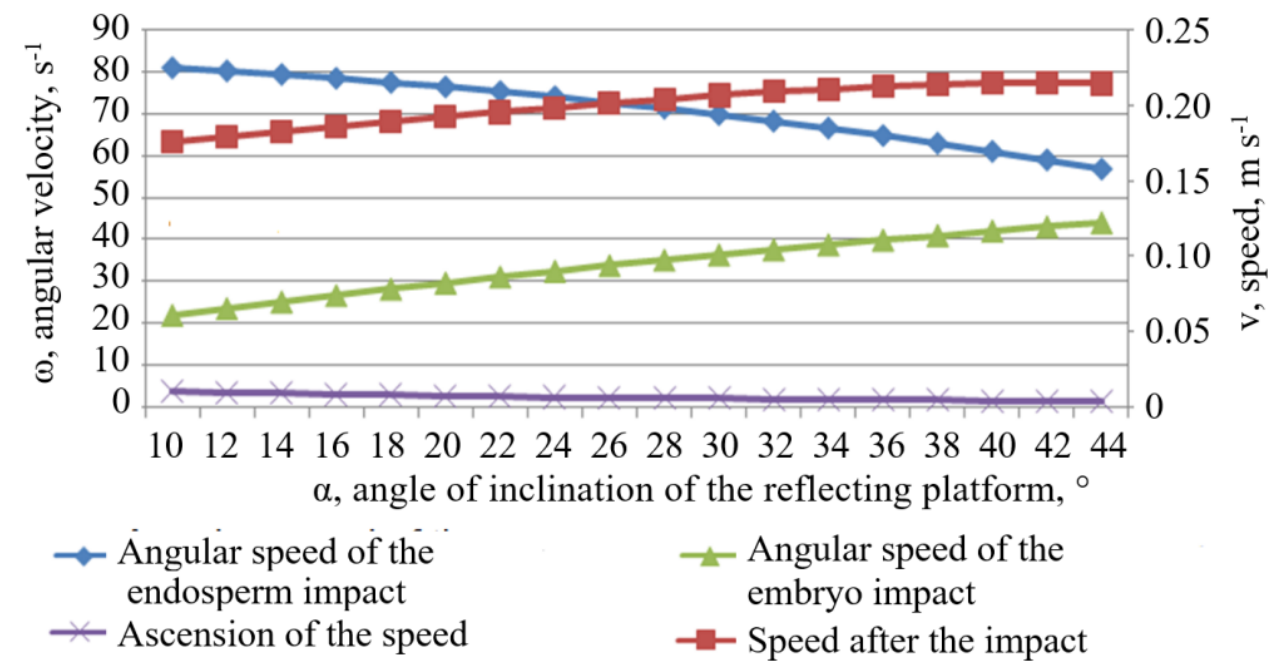

Figure 5. The rotation angles of the model's axis after the first impact the endosperm.

Table 1 shows the calculated data for the angles of rotation of the grain model axis after the second and third impacts. Taking into account the conclusions from the dependencies (Fig. 3), the initial velocity does not exceed $0.3 \mathrm{~m} \mathrm{~s}^{-1}$. To change the orientation of the grain axis, the rotation angle should exceed $95^{\circ}$.

The numerical experimental studies confirmed that positive orientation results are obtainable (Table 1) and that the process can be controlled by changing the angles of inclination and the length of the wall of the tray orientator in the range of working velocity before the impact of the grains at $0.2-0.3 \mathrm{~m} \mathrm{~s}^{-1}$, when the angles of the interaction planes are $24-32^{\circ}$. This finding is consistent with that of Polukoshko et al. (2015), who studied the dynamics of a rigid body that collides with a rigid surface. In their work, the authors presented vertical gravitational orientation of small prism-shaped workpieces on inclined guide surfaces and confirmed that impact can be used both for decreasing velocity and for the orientation of the tracking workpieces. When workpieces slide on inclined surfaces and fall freely on the surface below, they can change position during impact, inverting backwards. The conditions for post-impact inversion on rigid surface were established. For a body to invert, it is necessary that angular speed does not change a direction after impact and is sufficient for rotation in a desired direction. However, these conditions are insufficient in the case of the discussed grain model, since it takes only two positions after impact with the surface. Therefore, two more impacts on an inclined plane are necessary for the correct orientation of the object.

The experimental results from the orientation indicate the possibility of obtaining approx. $90 \%$ success in orienting grain, provided the flow density during free movement of the tray within the specified ranges of working velocity and angles of the impact plane are correct. 
Vladislav Zubko et al.

Table 1.

The rotation angles of the model's axis after the initial impact of the endosperm.

\begin{tabular}{cccc}
\hline $\begin{array}{l}\text { Initial velocity } \\
\mathrm{m} \mathrm{s}^{-1}\end{array}$ & $\begin{array}{c}\text { Angle of inclination of } \\
\text { the plane } \\
\left({ }^{\circ}\right)\end{array}$ & $\begin{array}{c}\text { Angle of rotation after } \\
\text { the 2nd impact } \\
\left({ }^{\circ}\right)\end{array}$ & $\begin{array}{c}\text { Angle of rotation after } \\
\text { the 3rd impact } \\
\left({ }^{\circ}\right)\end{array}$ \\
\hline 0.15 & & $44.225^{*}$ & $82.280^{*}$ \\
0.20 & 24 & 60.862 & 103.407 \\
0.25 & & 82.597 & 112.656 \\
0.30 & & 97.338 & 102.071 \\
\hline 0.15 & 28 & $51.794^{*}$ & $75.876^{*}$ \\
0.20 & & 70.993 & 113.505 \\
0.25 & & 94.102 & 111.857 \\
0.30 & & 114.372 & 222.147 \\
\hline 0.15 & 32 & $48.794^{*}$ & $64.403^{*}$ \\
0.20 & & 73.522 & 95.377 \\
0.25 & & 98.115 & 109.876 \\
0.30 & & 126.213 & 194.849 \\
\hline 0.15 & & $37.834^{*}$ & $32.891^{*}$ \\
0.20 & 36 & $63.066^{*}$ & $71.571^{*}$ \\
0.25 & & 89.226 & 104.150 \\
0.30 & & 118.020 & 157.519 \\
\hline 0.15 & & $-4.048^{*}$ & $-44.271^{*}$ \\
0.20 & & $39.268^{*}$ & $25.282^{*}$ \\
0.25 & & $67.923^{*}$ & $71.010^{*}$ \\
0.30 & & 96.402 & 114.618 \\
\hline$*$ & & &
\end{tabular}

* - non-working modes.

\section{Conclusion}

Theoretical research has been performed and numerical experiments on the orientation of winter wheat grains. A new geometric model of wheat grain with a displaced centre of mass, containing two end semispheres and amid-line truncated cone, has been developed. Further research should be undertaken to investigate the oval-shaped grain models, which will expand the scope of the orientation device.

A new method to calculate the multiple impact interaction between the grain and the inclined metal surfaces allows determining the ranges of the operating parameters of the orientation device. The study has demonstratedthe possibility to obtain positive orientation results and control of the process. This is done by changing the angles of inclination and the length of the wall of the tray orientator in the range of working velocity before the impact of the grains at $0.2-0.3 \mathrm{~m} \mathrm{~s}^{-1}$, when the angles of the interaction planes are $24-32^{\circ}$. The working efficiency of the orientation device in the grain flow was confirmed experimentally. The results indicate the possibility of obtaining approx. $90 \%$ success in orienting the grain. 
Further studies are needed to provide a full picture of the orientation process, taking into account the length of the inclined planes, the friction coefficients for various surfaces, and the coefficient of restitution of velocity after impact.

\section{Acknowledgements}

This research was supported by the Internal Grant Agency of the Faculty of Tropical AgriSciences, Czech University of Life Sciences Prague, project number [20205008]. The authors are grateful for the Czech Development Cooperation support, which allowed this scientific cooperation to start.

\section{References}

Boothroyd, G., Dewhurst, P. (2002). Product Design for Manufacture and Assembly. New York: Marcell Dekker, Inc. ISBN: 0-8247-0584-X

Borger, C., Hashem, A., Pathan, S. (2010). Manipulating crop row orientation to suppress weeds and increase crop yield. Weed Science, 58(2), 174-178. doi: 10.1614/WS-09-094.1

Bozhydarnik, V.V., Ghryghor'jeva, N.S., Shabajkovych, V. A. (2005). Automation of assembly of products. Lutsk: LDTU. (In Ukrainian).

Chenu, K., Porter, J., Martre, P., Basso, B., Chapman, S., Ewert, F., Bindi, M., Asseng, S. (2017). Contribution of crop models to adaptation in wheat. Trends in plant science, 22(6), 472-490. doi: 10.1016/j.tplants.2017.02.003

Chu, P., Zhang, Y., Yu, Z., Guo, Z., Shi, Y. (2016). Winter wheat grain yield, water use, biomass accumulation and remobilisation under tillage in the North China Plain. Field Crops Research, 193, 43-53. doi: 10.1016/j.fcr.2016.03.005

Dai, J., Wang, Z., Li, M., He, G., Li, Q., Cao, H., Wang, S., Gao, Y., Hui, X. (2016). Winter wheat grain yield and summer nitrate leaching: Long-term effects of nitrogen and phosphorus rates on the Loess Plateau of China. Field Crops Research, 196, 180-190. doi: 10.1016/j.fcr.2016.06.020

Dyakonov A.A., Shipulin L.V. (2016). Wheel-workpiece interaction in peripheral surface grinding. Russian Engineering Research, 36, 63-66. https://doi.org/10.3103/S1068798X16010093

Grishchenko, N.V., Roslyakov, V.S. (2009). The method of sowing corn and sowing apparatus for its implementation. Patent RF, no. 2343668. (In Russian).

Gusev, A.A. (1976). Automation and mechanization of assembly processes in small-scale and serial production. Moscow. (In Russian).

Koller, A., Taylor, R., Raun, W., Weckler, P., Buser, M. (2016). Modelling and validation of maize seed orientation by pushing. Biosystems Engineering, 151, 338-349. doi: 10.1016/j.biosystemseng.2016.09.011

Kouamé, K., Bernard, K., Kouakou, K., Kouassi, K., Jean-Pierre, B., Bi Irié, Z., Arsène, I. (2015). Effects of Seed orientation and sowing depths on Germination, Seedling vigor and yield in Oleaginous type of Bottle gourd, Lagenaria siceraria (Molina Standl). International Research Journal of Biological Sciences, 4(12), 46-53. 2278-3202. ISSN 2278-3202

Kuzina, T., Sirenko, V., Zubko, V., Chuba, V. (2018). Increasing yields of winter wheat by means of sowing orientation of grain Proceedings of the 17th International Scientific Conference Engineering for rural development, 687-694. doi: 10.22616/ERDev2018.17.N387

Lapshin, V.V. (2014). Planar problem elastic impact a body against an obstacle. Engineering Journal: Science and Innovation (electronic journal), 1(25). Available at: http://engjournal.ru/catalog/eng/teormech/1195.html [accessed 05.03.2014]

Lebedovskiy, M.S., Veyts, V.L., Fedotov, A.I. (1985). Scientific basis of automatic assembly. Leningrad. (In Russian). 
Maiatskaia, I.A. (1999). Development of mechanical-mathematical models of seeds of agricultural crops harvested by combines (PhD Thesis), Rostov-on-Don: Rostov-on-Don State Academy of Agricultural Engineering. (In Russian).

Polukoshko, S., Kononova, O., Sokolova, S. (2015). Gravity-operated impact feeder dynamics. Proceedings of the 7th International Scientific and Practical Conference. Environment. Technology. Resources, 214-221. doi: 10.17770/etr2009vol2.1042.

Redford, A., Chal, J. (1994). Design for Assembly: Principles and Practice Publisher: McGraw-Hill. ISBN-10: 0077078381

Schillinger, W., Donaldson, E., Allan, R., Jones, S. (1998). Winter Wheat Seedling Emergence from Deep Sowing Depths. Agronomy Journal, 90(5). doi: 10.2134/agronj1998.00021962009000050 $002 x$

Suri, R. (1995). Design and Analysis of Manufacturing Systems. University of Wisconsin.

Torres, G., Koller, A., Taylor, R., Raun, W. (2017). Seed-oriented planting improves light interception, radiation use efficiency and grain yield of maize (Zea mays L.). Experimental Agriculture, 53(2), 210-225. doi:10.1017/S0014479716000326

Troshkin, D., Chertov, A., Gorbunova, E., Baranov, I., Mironova, D., Kushkoeva, A., Zuev, E., Loskutov, I. (2019). A study of the influence of the orientation and arrangement features of wheat grains and their color on determination of the vitreousity. Automated Visual Inspection and Machine Vision III, 110610K. doi: 10.1117/12.2526018

Uniyal, A., Singh, B., Todaria, N. (2007). Effects of Seed Size, Sowing Orientation and Depth on Germination and Seedling Growth in Neem, Azadirachta indica. Seed Technology, 29(1), 68-75.

Vladzievskiy, A.P., Belousov, A.P. (1966). Fundamentals of automation and mechanization of technological processes in mechanical engineering. Moscow: Vysshaya shkola. (In Russian).

Zavgorodniy, A.I., Romanyuk, G.S., Sheptur, A.A., Obykhvost, A.V. (2010). Ensuring the technological mode of movement of the spherical particle on the vibroseparator deck. Mechanization of agricultural production: Bulletin of the Kharkiv National Technical University of Agriculture named after Peter Vasylenko, 1(93), 205-214.

Zotikov, A.S., Lashkov, V.A. (2014). Restitution coefficient of velocity at impact of absolutely elastic particle with shape of an ellipsoid of revolution. Bulletin of st. Petersburg state university. Series 1. Mathematics. Mechanics. Astronomy, 1(59), 245-253.

Zubko, V.M., Sirenko, V.F., Plavinsky, V.I., Kuzina, T.V. (2017a). Grain-sowing device. Patent UA, no. 113823. (In Ukrainian).

Zubko, V.M., Sirenko, V.F., Plavinsky, V.I., Kuzina, T.V. (2017b). Method of placement of winter wheat seeds in the soil under sowing. Patent UA, no. 113837. (In Ukrainian). 


\title{
MODELOWANIE PRZEPLYWU ZIAREN PSZENICY PODCZAS SIEWU W OPARCIU O MODEL ZIARNIAKA Z PRZESUNIĘTYM ŚRODKIEM CIĘŻKOŚCI
}

\begin{abstract}
Streszczenie. Pszenica ozima jest jedną z najpopularniejszych roślin uprawnych na Ukrainie. Poszukiwanie metod zwiększenia plonów i właściwości konsumpcyjnych pszenicy, bez uszczerbku dla bezpieczeństwa środowiska, stanowi zatem ważny problem naukowy. Zasady rolnictwa precyzyjnego podkreślają właściwe rozmieszczenie nasion, zalecając pionowe ustawienie kiełków pszenicy (metoda „kiełkowania w górę”). Głównym celem badań było opracowanie nowego modelu geometrycznego ziarna pszenicy z przesuniętym środkiem ciążkości oraz przeprowadzenie badań teoretycznych i eksperymentów obliczeniowych dotyczących orientacji ziaren. Bazowały one na wielokrotnym zderzaniu z powierzchniami nachylonymi. Zaproponowano nowy model ziarniaka, składający się z dwóch różnych półkul końcowych i amidoliniowego stożka ściętego, z przesuniętym środkiem ciężkości. Zastosowano koncepcję układu orientacji grawitacyjnej nasion, z uwzględnieniem właściwości fizycznych obiektów. Koncepcja ta opierała się na różnych relacjach między parametrami kinetycznymi ciał z przesuniętym środkiem ciężkości po zderzeniu. Wyniki pokazały, że procesem orientacji można sterować poprzez zmianę kątów nachylenia i długości ścianek tacy podajnika w zakresie prędkości roboczych, pod warunkiem, że robi się to przed zderzeniem o wartości $0,2-0,3 \mathrm{~m} \mathrm{~s}^{-1}$, gdy kąty nachylenia płaszczyzn oddziaływania zderzeniowego wynoszą $24-32^{\circ} \mathrm{C}$.
\end{abstract}

Słowa kluczowe: ziarniak, model ziarna, wpływ położenia, orientacja nasion, pszenica ozima 